УДК 339.13: 663.21

DOI: $10.15673 /$ fie.v10i3.1061

\author{
Фомішина В.M. \\ доктор економічних наук, професор \\ E-mail: fomishyna.vira@kntu.net.ua \\ Федорова Н.€. \\ аспірант \\ кафедра зовнішньоекономічної діяльності \\ Херсонський національний технічний університет, \\ Бериславське шосе, 24, м. Херсон, Україна, 73008 \\ E-mail: fedorova.nadiya@kntu.net.ua
}

\title{
ВИЗНАЧЕННЯ РІВНЯ АДАПТАЦІЇ КОМУНІКАТИВНОЇ СКЛАДОВОЇ КОМПЛЕКСУ МАРКЕТИНГУ ВИНОРОБНОГО ПІДПРИЄМСТВА (НА ПРИКЛАДІ ПРАТ «КНЯЗЯ ТРУБЕЦЬКОГО»)
}

У статті обґрунтовано важливість пристосування підприємства до мінливого зовнішнього середовища його функціонування. Висвітлено категорію «адаптація комунікативної складової комплексу маркетингу» підприємства. Дано методику визначення рівня адаптації комунікативної складової комплексу маркетингу виноробного підприємства. Охарактеризовано зовнішнє середовище виноробних підприємств Херсонської області у 2013-2017 рр. Визначено елементи внутрішнього середовища підприємства виноробної промисловості (на прикладі ПрАТ «Князя Трубецького»). Встановлено наявний рівень адаптації комунікативної складової комплексу маркетингу підприємства. Виявлено взаємозв'язок між рівнем адаптації комунікативної складової комплексу маркетингу та валовим прибутком підприємства. Визначено невикористані можливості підвищення ефективності функціонування підприємства за рахунок зростання рівня адаптації комунікативної складової комплексу маркетингу.

Ключові слова: адаптація, рівень адаптації, комунікативна складова, маркетингові комунікації, комплекс маркетингу, зовнішнє середовище, внутрішнє середовище, виноробна промисловість.

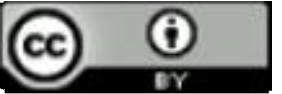

This work is licensed under a Creative Commons Attribution 4.0 International License http://creativecommons.org/licenses/by/4.0/
Постановка проблеми та її зв'язок з важливими науковими та практичними завданнями. Сучасні умови господарювання підприємств виноробної промисловості, коли зростає ступінь мінливості зовнішнього середовища і загостюється конкуренція, вимагають від підприємств пристосування до їхньої дії через адаптацію всіх напрямів діяльності, зокрема, комплексу маркетингу та його складових. Адже саме адаптація надає підприємству можливість уникати кризових явищ, ефективно конкурувати та розширює діапазон його ринкових можливостей [1, с.38].

Аналіз останніх публікацій по проблемі. Результати досліджень різних аспектів адаптації підприємства до мінливого зовнішнього середовища розкрито у роботах таких авторів: Будник М.М. [3], Шевченко В.В. [4], Райзберг Б.А., Лозовский Л.Ш., Стародубцева Е.Б. [5], Бричко А.М. [7], Дудчак В.В. [8], Артеменко В.Б., Агафонова М.С. [9], Пастухова Є.А., Марковська Є.I. [11], Зяблицька Н.В. [12], Ластаєв Т.Т. [13], Алєксєєв С.Б. [14]. Термін «адаптація» використовується у широкому колі наук, в кожній 3 яких трактується 3 урахуванням особливостей предмету вивчення та мети дослідження. За походженням поняття «адаптація» $\epsilon$ латинським, в перекладі від «adapto» означає «пристосовувати» [2]. У вітчизняній та зарубіжній економічній літературі розглядаються поняття «адаптація», «економічна адаптація», «адаптація підприємства». Ряд дослідників [3, с.6; 4, с.24] трактують адаптацію як результат або кінцевий етап процесу пристосування, який характеризується досягненням поставлених цілей і задач і призводить до покращення його стану. Деякі використовують буквальний переклад і визначають адаптацію як пристосування [5, с. 13] або здатність виявляти пристосувальну поведінку [6, с.12] в складних середовищах. Також існує визначення, що адаптацією є реакція [7] економічної системи на зміну зовнішнього середовища та вид взаємодії [8] суб'єкта господарювання 3 соціально-економічним середовищем.

Більша ж частина науковців розглядають адаптацію як процес 1) перетворення [9, с.1996], взаємодії і пристосування [10, с.79; 11, с.7], зміни факторів [12] / параметрів [13, с.10], розроблення і реалізації дій $[14$, с.8], спрямованих на зміну внутрішнього середовища, враховуючи обмеженість його ресурсів, у відповідність вимогам зовнішнього за допомогою особливих адаптаційних механізмів. В рамках даного дослідження, адаптація комунікативної складової комплексу маркетингу підприємства $\epsilon$ процесом розроблення і реалізації найбільш дієвого переліку засо- 
бів маркетингових комунікацій із врахуванням особливостей характеру діяльності підприємства та в умовах мінливості зовнішнього середовища його функціонування, що призведе до зростання ефективності діяльності підприємства.

Формулювання цілей дослідження. Метою даного дослідження $\epsilon$ дослідження рівня адаптації комунікативної складової комплексу маркетингу виноробного підприємства, знаходження резервів його зростання для розроблення в подальшому рекомендацій щодо підвищення ефективності діяльності підприємства (зростання валового прибутку).
Виклад основних результатів та їх обгрунтування. Динаміку рівня адаптації комунікативної складової комплексу маркетингу (КСКМ) досліджуваного підприємства визначимо відповідно до результатів аналізу складових зовнішнього та внутрішнього середовищ. Для цього побудуємо матриці співвідношення факторів зовнішнього та внутрішнього середовища функціонування. Найбільш впливові можливості і загрози зовнішнього середовища обрано згідно попередньо проведеної експертної оцінки. Серед можливостей обрано лише ті, що розташовані в полі «висока ймовірність із сильним впливом» та «середня ймовірність із сильним впливом» (табл. 1).

Таблиця 1

Перелік можливостей зовнішнього середовища функціонування підприємств виноробної промисловості*

\begin{tabular}{|c|c|l|}
\hline № & Шифр & \multicolumn{1}{|c|}{ Назва можливості } \\
\hline О1 & ПП1.5 & $\begin{array}{l}\text { Скасування плати за ліцензію на оптову торгівлю у розмірі } 500 \text { тис. грн. для підприємств, які } \\
\text { виробляють продукцію із власної сировини }\end{array}$ \\
\hline О2 & ПП3 & Ініціатива президента у започаткуванні свята українського винороба \\
\hline О3 & ПГК1 & $\begin{array}{l}\text { Відповідність природно-кліматичних умов вимогам вирощування винограду для виготовлення } \\
\text { тихих вин }\end{array}$ \\
\hline О4 & СД4 & Випередження вином горілки, яка вважається традиційним алкогольним напоєм \\
\hline О5 & СД5 & $\begin{array}{l}\text { Активна державна політика щодо обмеження шкідливого впливу споживання алкогольних } \\
\text { напоїв }\end{array}$ \\
\hline О6 & Е4 & Зростання значення Херсонської області як виноробного регіону \\
\hline О7 & К1 & Ринок монополістичної конкуренції \\
\hline О8 & К2 & Зниженням концентрації ринку \\
\hline
\end{tabular}

Серед загроз обрано ті, що знаходяться в полях «висока ймовірність руйнування», «середня ймовірність руйнування», «висока ймовірність критичного стану», «середня ймовірність критичного стану», а також «висока ймовірність важкого стану» стосовно обмежень щодо використання засобів маркетингових комунікацій (табл. 2).

Перелік загроз зовнішнього середовища функціонування підприсмств виноробної промисловості*

\begin{tabular}{|c|c|l|}
\hline № & Шифр & \multicolumn{1}{|c|}{ Назва можливості } \\
\hline Т1 & ПП.1.6 & Законодавчі обмеження щодо рекламування тихих вин \\
\hline Т2 & ПП4 & Підписання Угоди про асоціацію між Україною та СС \\
\hline Т3 & ПП5 & Втрата третини виноробної галузі через від’єднання АР Крим у 2014 році \\
\hline Т4 & СД1 & Зниження чисельності населення \\
\hline Т5 & СД2 & Зниження частки витрат населення на алкогольні напої та тютюнові вироби \\
\hline Т6 & К3 & Зростанням кількості учасників ринку \\
\hline Т7 & К4 & Низька ділова активність \\
\hline Т8 & К5 & Низький обсяг споживання вина \\
\hline Т9 & К6 & Відсутність стійкої лояльності споживачів до торговельної марки \\
\hline
\end{tabular}

До сильних і слабких сторін підприємства було обрано фактори внутрішнього середовища ПрАТ «Князя Трубецького» на основі попередньої експертної оцінки. Сильні сторони підприємства наведено у табл.3. табл.4.

Слабкі сторони підприємства наведено у

Рівень адаптації КСКМ було визначено відповідно до того як підприємство втілює в життя на- прями реалізації КСКМ згідно наявних умов зовнішнього і внутрішнього середовища. Відповідно до сучасних ринкових умов, які формують можливості та загрози для роботи виноробних підприємств, та, враховуючи внутрішній потенціал ПрАТ «Князя Трубецького», було виділено 4 групи напрямів реалізації заходів комунікативної складової комплексу маркетингу: SO, WO, ST та WT. 
Перелік сильних сторін внутрішнього середовища ПрАТ «Князя Трубецького»*

\begin{tabular}{|c|l|}
\hline № & \multicolumn{1}{|c|}{ Назва можливості } \\
\hline S1 & Особливості технології виробництва продукції \\
\hline S2 & Наявність власної сировини \\
\hline S5 & Набір використовуваних засобів маркетингових комунікацій \\
\hline S6 & Диверсифікованість каналів збуту \\
\hline S7 & Рівень відомості ТМ серед споживачів \\
\hline S9 & Наявність спеціаліста з маркетингу на підприємстві \\
\hline S10 & Зростання фінансових результатів діяльності \\
\hline \multicolumn{2}{|c|}{ *кладено авторами на основі експертної оцінки } \\
\hline
\end{tabular}

Таблиця 4

Перелік слабких сторін внутрішнього середовища ПрАТ «Князя Трубецького»*

\begin{tabular}{|c|l|}
\hline № & \multicolumn{1}{|c|}{ Назва можливості } \\
\hline W3 & Широта асортименту \\
\hline W4 & Невідповідність асортименту перевагам споживачів (згідно проведеного опитування) \\
\hline W8 & Розмір ринкової частки \\
\hline \multicolumn{2}{|c|}{ *Сладено авторами на основі експертної оцінки } \\
\end{tabular}

SO-напрями передбачають використання сильних сторін підприємства для реалізації можливостей зовнішнього середовища за рахунок використання засобів комунікативної складової комплексу маркетингу:

SO1. Спрямування додаткових коштів, отриманих за рахунок скасування плати за ліцензію на оптову торгівлю для підприємств, які виробляють продукції із власної сировини, на розширення комплексу маркетингових комунікацій.

SO2. Розширення охоплення цільової аудиторії за рахунок участі у всеукраїнських заходах щодо святкування дня винороба, започаткованого президентом у 2017 році.

SO3. Включення до змісту КСКМ інформації щодо особливостей терруару Херсонської обл. та відповідних характеристик, які набувають вина, за рахунок природно-географічних та кліматичних умов.

SO4. Підтримання інтересу споживачів до тихих вин, а також формування культури споживання та завоювання лояльності цільової аудиторії.

SO5. Використання інструментарію зв'язків iз громадськістю для підтримки державних соціальних програм щодо помірного споживання алкогольних напоїв та формування культури споживання вина.

SO6. Використання методів нецінової конкуренції, зокрема, стратегії диференціації іміджу для формування стійких зв'язків зі споживачем.

SO7. Формування бар'єрів для входу нових гравців у галузь за рахунок стійкої лояльності споживачів до торговельної марки.

ST-напрями складають комплекс заходів щодо нівелювання загроз зовнішнього середовища за рахунок використання сильних сторін при побудові КСКМ:

ST1. Врахування переваг споживачів щодо джерел отримання інформації про вино при побудові комплексу маркетингових комунікацій підприємства.

ST2. Формування стійкої лояльності споживачів до внутрішніх виробників за рахунок просування ідеї високої якості вин.
ST3. Розроблення комплексу маркетингових комунікацій, який сприятиме підвищенню споживчої цінності торговельної марки (з врахуванням критеріїв вибору вина), що сприятиме зростанню лояльності до торговельної марки.

ST4. Формування у свідомості споживачів індивідуального іміджу торговельної марки за допомогою КСКМ.

ST5. Стимулювання попиту на вина шляхом ефективної комбінації засобів КСКМ.

ST6. Встановлення стійких довгострокових взаємовигідних зв'язків між підприємствами і споживачами за рахунок КСКМ.

WO-напрями передбачають використання можливостей зовнішнього середовища для нівелювання слабких сторін шляхом використання засобів комунікативної складової комплексу маркетингу:

WO1. Використання зростання інтересу споживачів до вина для формування смаку до сухих вин, які найбільш популярні серед споживачів «традиційних винних країн» (Франція, Італія, Іспанія тощо).

WO2. Завоювання більшої частки ринку за рахунок структурних змін у конкурентному середовищі ринку.

WT-напрями передбачають реалізацію таких заходів комунікативного впливу, що компенсують слабкі сторони підприємства та загрози зовнішнього середовища за рахунок наявних ресурсів підприємства:

WT1. Використання найбільш ефективних засобів маркетингових комунікацій для формування стійкої лояльності споживачів до торговельної марки.

Максимально можливий рівень адаптації КСКМ (РА $\operatorname{mCKM}_{\text {M }}$ ) визначається як сума всіх напрямів реалізації КСКМ згідно наявних умов зовнішнього та внутрішнього середовища функціонування підприємства: 


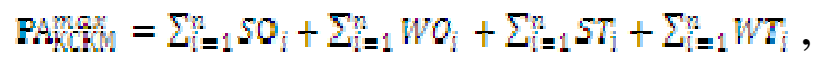

Наявний рівень адаптації КСКМ - сума всіх напрямів реалізації КСКМ, використаних підприємством у досліджуваному періоді.
Визначення напрямів реалізації заходів КСКМ у 2017 році для ПрАТ «Князя Трубецького» наведено у табл. 5.

Таблиця 5

Матриця визначення напрямів реалізації заходів КСКМ ПрАТ «Князя Трубецького» у 2017 році*

\begin{tabular}{|c|c|c|c|c|c|}
\hline \multirow{2}{*}{\multicolumn{2}{|c|}{$\begin{array}{r}\text { Фактори зовнішнього } \\
\text { середовища }\end{array}$}} & \multicolumn{2}{|c|}{$\begin{array}{c}\text { Можливості зовнішнього } \\
\text { середовища }\end{array}$} & \multicolumn{2}{|c|}{$\begin{array}{c}\text { Загрози зовнішнього } \\
\text { середовища }\end{array}$} \\
\hline & & $\begin{array}{l}\text { O1. - ПП1.5 } \\
\text { О2. - ПП3 } \\
\text { О3. - ПГК } 1 \\
\text { О4. - СД4 } \\
\text { О5. - СД5 } \\
\text { О6. - Е4 } \\
\text { О7. - К1 } \\
\text { О8. - відсутня }\end{array}$ & $\begin{array}{l}7,23 \\
6,88 \\
9,00 \\
6,88 \\
5,33 \\
5,63 \\
6,92 \\
-\end{array}$ & $\begin{array}{l}\text { Т1. - ПП1.6 } \\
\text { Т2. - ПП4 } \\
\text { Т3. - ПП5 } \\
\text { Т4. - СД1 } \\
\text { Т5. - відсутня } \\
\text { Т6. - К3 } \\
\text { Т7. - К4 } \\
\text { Т8. - К5 } \\
\text { Т9. - К6 }\end{array}$ & $\begin{array}{c}4,7 \\
8,75 \\
6,88 \\
5,25 \\
- \\
6,26 \\
6,75 \\
12,00 \\
11,52\end{array}$ \\
\hline $\begin{array}{l}\text { Сильні сторони } \\
\text { S1 } \\
\text { S2 } \\
\text { S5 } \\
\text { S6 } \\
\text { S7 } \\
\text { S9 } \\
\text { S10 }\end{array}$ & $\begin{array}{l}0,084 \\
0,129 \\
0,119 \\
0,090 \\
0,100 \\
0,069 \\
0,100\end{array}$ & \begin{tabular}{l} 
SO-напрями реалізації \\
\multicolumn{1}{c}{ КСКМ: } \\
1. O1*S10 \\
2. O2*S1,5 \\
3. O3,6*S1,2 \\
4. O4*S $5,6,7,9$ \\
5. O5*S $5,6,7$ \\
6. O7*S5,6,7,9 \\
7. -
\end{tabular} & $\begin{array}{c}0,723 \\
1,397 \\
3,116 \\
2,601 \\
1,647 \\
2,616 \\
-\end{array}$ & $\begin{array}{l}\text { ST- напрями реалізації } \\
\quad \text { КСКМ: } \\
\text { 1. T1*S5 } \\
\text { 2. T2*S1,2,5,6,7,9 } \\
\text { 3.T4*S5,6,9 } \\
\text { 4. T6*S1,2,5 } \\
\text { 5. T7,8*S5 } \\
\text { 6. T3,T9*S5 }\end{array}$ & $\begin{array}{l}0,559 \\
5,171 \\
1,460 \\
2,078 \\
2,231 \\
2,190\end{array}$ \\
\hline $\begin{array}{l}\text { Слабкі сторони } \\
\text { (W) } \\
\text { W3 } \\
\text { W4 } \\
\text { W8 }\end{array}$ & $\begin{array}{l}0,025 \\
0,038 \\
0,023\end{array}$ & $\begin{array}{l}\text { WO- напрями реалізації } \\
\text { КСКМ: } \\
\text { 1. O3,4,6*W3,4 } \\
\text { 2. O3,5,6,7*W8 }\end{array}$ & $\begin{array}{l}1,335 \\
0,618\end{array}$ & $\begin{array}{l}\text { WT- напрями реалізації } \\
\text { КСКМ: } \\
\text { 1. T2,3,4*W8 }\end{array}$ & 0,480 \\
\hline \multicolumn{4}{|c|}{ Максимально можливий рівень адаптації КСКМ, балів } & \multicolumn{2}{|l|}{28,242} \\
\hline \multicolumn{4}{|c|}{ Наявний рівень адаптації КСКМ, балів } & \multicolumn{2}{|l|}{24,113} \\
\hline
\end{tabular}

*Складено авторами на основі табл. 1-5

2017 рік:

SO-напрями:

$\mathrm{SO} 1=\mathrm{O} 1 * \mathrm{~S} 10=7,23 * 0,100=0,723$.

$\mathrm{SO} 2=\mathrm{O} 2 * \mathrm{~S} 1,5=6,55 *(0,084+0,119)=1,397$.

$\mathrm{SO} 3=\mathrm{O} 3,6 * \mathrm{~S} 1,2=(9,00+5,63) * 0,084+0,129)=3,116$.

$\mathrm{SO} 4=\mathrm{O} 4 * \mathrm{~S} 5,6,7,9=6,88 *(0,119+0,090+0,100+0,069)=$ $=2,601$.

$\mathrm{SO} 5=\mathrm{O} 5 * \mathrm{~S} 5,6,7=5,33 *(0,119+0,090+0,100)=1,647$.

$\mathrm{SO} 6=\mathrm{O} 7 * \mathrm{~S} 5,6,7,9=6,92 *(0,119+0,090+0,100+0,069)=$ $=2,616$.

ST-напрями:

$\mathrm{ST} 1=\mathrm{T} 1 * \mathrm{~S} 5=4,7 * 0,119=0,559$.

$\mathrm{ST} 2=\mathrm{T} 2 * \mathrm{~S} 1,2,5,6,7,9=8,75 *(0,084+0,129+0,119+0,090+$ $+0,100+0,069)=5,171$.

ST3 $=$ T4 $*$ S5 $, 6,9=5,25 *(0,119+0,090+0,069)=1,460$.
$\mathrm{ST} 4=\mathrm{T} 6 * \mathrm{~S} 1,2,5=6,26 *(0,084+0,129+0,119)=2,078$.

$\mathrm{ST} 5=\mathrm{T} 7,8 * \mathrm{~S} 5=(6,75+12,00) * 0,119=2,231$.

ST $6=\mathrm{T} 3,9 * \mathrm{~S} 5=(6,88+11,52) * 0,119=2,190$.

$\mathrm{WO} 1=03,4,6 * \mathrm{~W} 3,4=(9,00+6,88+5,63) *(0,025+0,038)=$ $=1,335$.

$\mathrm{WO} 2=\mathrm{O} 3,5,6,7 * \mathrm{~W} 8=(9,00+5,33+5,63+6,92) * 0,023=$ $=0,618$.

$\mathrm{WT} 1=\mathrm{T} 2,3,4 * \mathrm{~W} 8=(8,75+6,88+5,25) * 0,023=0,480$.

Напрями реалізації заходів КСКМ ПрАТ «Князя Трубецького» у 2013-2016 рр. розраховані аналогічно. Відповідність наявного рівня адаптації КСКМ ПрАТ «Князя Трубецького» сучасним ринковим умовам у 2013-2017 pр. наведено у табл. 6. 
Таблиця 6

Визначення рівня адаптації КСКМ ПрАТ «Князя Трубецького» у 2013-2017 рр.*

\begin{tabular}{|c|c|c|c|c|c|c|c|c|}
\hline \multirow[b]{2}{*}{$\begin{array}{l}\text { № } \\
\text { 3/ח }\end{array}$} & \multirow[b]{2}{*}{$\begin{array}{l}\text { Напрями } \\
\text { адаптації } \\
\text { КСКМ }\end{array}$} & \multirow[b]{2}{*}{ Реалізація напряму підприємством } & \multirow{2}{*}{$\begin{array}{c}\text { Відповід- } \\
\text { ність } \\
\text { напряму } \\
\text { адаптації } \\
(+/-)\end{array}$} & \multicolumn{5}{|c|}{ Бальна оцінка } \\
\hline & & & & 2013 & 2014 & 2015 & 2016 & 2017 \\
\hline 1. & SO1 & $\begin{array}{l}\text { Зростання обсягів коштів, виділених } \\
\text { для просування продукції у досліджу- } \\
\text { ваному періоді. }\end{array}$ & + & - & - & - & 0,723 & 0,723 \\
\hline 2. & $\mathrm{SO} 2$ & $\begin{array}{l}\text { Вперше святкування передбачене у } \\
2018 \text { році. }\end{array}$ & - & - & - & - & - & 0,000 \\
\hline 3. & $\mathrm{SO} 3$ & $\begin{array}{l}\text { Висвітлюється на офіційному сайті та } \\
\text { під час екскурсії на підприємство. }\end{array}$ & + & 1,917 & 3,116 & 3,116 & 1,917 & 3,116 \\
\hline 4. & $\mathrm{SO} 4$ & $\begin{array}{l}\text { Проведення дегустацій, заходів типу } \\
\text { «Вечеря в форматі фудпейрінг», засі- } \\
\text { дань «Винного клубу» на території } \\
\text { господарства. }\end{array}$ & + & - & - & - & - & 2,601 \\
\hline 5 . & SO5 & $\begin{array}{l}32015 \text { року на території господарства } \\
\text { проводяться заходи (дегустацій, захо- } \\
\text { дів типу «Вечеря в форматі фудпей- } \\
\text { рінг», засідань «Винного клубу» то- } \\
\text { що), що сприяють підвищенню куль- } \\
\text { тури споживання вина }\end{array}$ & + & 0,000 & 0,000 & 1,647 & 1,647 & 1,647 \\
\hline 6. & SO6 & $\begin{array}{l}\text { Торговельна марка має власний імідж, } \\
\text { історію та стратегію позиціонування. }\end{array}$ & + & 1,924 & 2,616 & 2,616 & 2,616 & 2,616 \\
\hline 7. & SO7 & $\begin{array}{l}\text { Опитування споживачів Херсонської } \\
\text { обл. виявило низький рівень лояльно- } \\
\text { сті споживачів до торговельних ма- } \\
\text { рок. }\end{array}$ & - & 1,829 & 2,487 & - & - & - \\
\hline 8. & ST1 & $\begin{array}{l}\text { На території господарства у фірмово- } \\
\text { му магазині та під час дегустації спо- } \\
\text { живачі мають можливість отримати } \\
\text { професіональну консультацію; підп- } \\
\text { риємство має сторінку у Facebook; } \\
\text { використовує POS-матеріали. }\end{array}$ & + & 0,559 & 0,559 & 0,559 & 0,559 & 0,559 \\
\hline 9. & ST2 & $\begin{array}{l}\text { Вина господарства мають численні } \\
\text { нагороди, що відображене у КСКМ. }\end{array}$ & + & - & 5,171 & 5,171 & 5,171 & 5,171 \\
\hline 10. & ST3 & $\begin{array}{l}\text { Окрім смаку та якості, важливим кри- } \\
\text { терієм визначено органічність вина, } \\
\text { що не відображено у КСКМ. }\end{array}$ & - & 0,000 & 0,000 & 0,000 & 0,000 & 0,000 \\
\hline 11. & ST4 & $\begin{array}{l}\text { Торговельна марка має власний імідж, } \\
\text { історію та стратегію позиціонування. }\end{array}$ & + & 2,078 & 2,078 & 2,078 & 2,078 & 2,078 \\
\hline 12. & ST5 & $\begin{array}{l}\text { Підприємство використовує досить } \\
\text { широкий набір засобів КСКМ, як ос- } \\
\text { новних, так і синтетичних. }\end{array}$ & + & 2,231 & 2,231 & 2,231 & 2,231 & 2,231 \\
\hline 13. & ST6 & $\begin{array}{l}\text { Опитування споживачів Херсонської } \\
\text { обл. виявило низький рівень лояльно- } \\
\text { сті споживачів до торговельних ма- } \\
\text { рок. }\end{array}$ & - & 0,000 & 0,000 & 0,000 & 0,000 & 0,000 \\
\hline 14. & WO1 & $\begin{array}{l}\text { Проведення дегустацій, заходів типу } \\
\text { «Вечеря в форматі фудпейрінг», засі- } \\
\text { дань «Винного клубу» на території } \\
\text { господарства. }\end{array}$ & + & - & - & - & 0,922 & 1,355 \\
\hline 15. & WO2 & $\begin{array}{l}\text { У досліджуваному періоді частка рин- } \\
\text { ку становила менше } 1 \text { відсотка, проте } \\
\text { обсяги реалізованої продукції зроста- } \\
\text { ють. }\end{array}$ & + & 0,000 & 0,000 & 0,000 & 0,618 & 0,618 \\
\hline 16. & WT1 & $\begin{array}{l}\text { КСКМ потребує корегування для під- } \\
\text { вищення лояльності до торговельної } \\
\text { марки. }\end{array}$ & - & 0,000 & 0,000 & 0,000 & 0,000 & 0,000 \\
\hline & & івень адаптації КСКМ підприємства & & 8,710 & 15,772 & 18,037 & 19,682 & 24,113 \\
\hline
\end{tabular}

*Складено авторами на основі аналізу діяльності підприємства 
Показники наявного та максимально можливого рівня адаптації комунікативної складової комплексу маркетингу ПрАТ «Князя Трубецького» у
2013-2016 рр. розраховано аналогічно. Узагальнення результатів розрахунків наведено у табл. 7.

Таблиця 7

Динаміка рівня адаптації комунікативної складової комплексу маркетингу ПрАТ «Князя Трубецького» у 2013-2017 рp.*

\begin{tabular}{|c|c|c|c|c|c|c|c|c|c|c|}
\hline \multirow[b]{3}{*}{ Показник } & \multicolumn{10}{|c|}{ Рік } \\
\hline & \multicolumn{2}{|c|}{2013} & \multicolumn{2}{|c|}{2014} & \multicolumn{2}{|c|}{2015} & \multicolumn{2}{|c|}{2016} & \multicolumn{2}{|c|}{2017} \\
\hline & $\begin{array}{c}\text { Зна- } \\
\text { чення, } \\
\text { балів }\end{array}$ & $\mathrm{T}_{3 \mathrm{p}}$ & $\begin{array}{c}\text { Зна- } \\
\text { чення, } \\
\text { балів }\end{array}$ & $\begin{array}{c}\mathrm{T}_{3 \mathrm{p}} \\
2014 / \\
2013\end{array}$ & $\begin{array}{c}\text { Зна- } \\
\text { чення, } \\
\text { балів }\end{array}$ & $\begin{array}{c}\mathrm{T}_{3 \mathrm{p}} \\
2015 / \\
2014\end{array}$ & $\begin{array}{c}\text { Зна- } \\
\text { чення, } \\
\text { балів }\end{array}$ & $\begin{array}{c}T_{3 p} \\
2016 / \\
2015\end{array}$ & $\begin{array}{c}\text { Зна- } \\
\text { чення, } \\
\text { балів }\end{array}$ & $\begin{array}{c}T_{3 p} \\
2017 / \\
2016\end{array}$ \\
\hline PAREA & 14,934 & - & 26,499 & 77,441 & 24,012 & $-9,385$ & 25,656 & 6,847 & 28,242 & 10,080 \\
\hline PA & 8,710 & - & 15,772 & 81,079 & 18,037 & 14,361 & 19,682 & 9,120 & 24,113 & 22,513 \\
\hline 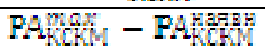 & 6,224 & - & 10,727 & 72,349 & 5,975 & $-44,299$ & 5,974 & $-0,017$ & 4,129 & $-30,88$ \\
\hline
\end{tabular}

*Складено авторами на основі аналізу діяльності підприємства

У досліджуваному періоді рівень адаптації КСКМ ПрАТ «Князя Трубецького» зростає, проте темп зростання не має сталої тенденції. Це можна пояснити мінливістю умов зовнішнього середовища функціонування підприємства. Що підтверджує показник максимально можливого рівня адаптації КСКМ. Перелік можливостей і загроз зовнішнього середовища змінюється, що змінює кількість можливих напрямів реалізації КСКМ для підприємства. Позитивною тенденцією $є$ те, що різниця між максимально можливим і наявним рівнем адаптації КСКМ у 20152017 рр. зменшується. Отже, використовувані підприємством засоби КСКМ враховують тенденції зовнішнього середовища.

Проте, визначення рівня адаптації комунікативної складової комплексу маркетингу ПрАТ «Князя Трубецького» показує, що 3-поміж шістнадцяти можливих напрямів адаптації підприємство у досліджуваному періоді реалізовує дев'ять; один 3 них (SO2) може бути реалізовано у майбутньому періоді, один не може бути використано на даний момент (SO7) через зміни у конкурентному середовищі ринку. Не використано підприємством такі напрями:

- ST3: використання інформації щодо органічності вин при формуванні КСКМ, що, згідно опитування, є важливим критерієм вибору вина для споживачів $(+1,460$ 6балів);

- ST6+WT1: підвищення рівня лояльності споживачів за допомогою такого набору засобів маркетингових комунікацій, який найбільш сприяє іiї формуванню $(2,190+0,480=+2,670$ балів $)$.

За допомогою програмного забезпечення Мicrosoft Excel проведемо кореляційно регресійний аналіз залежності обсягу валового прибутку, скорегованого з врахуванням індексу споживчих цін (див. табл. 8), ПрАТ «Князя Трубецького» від рівня адаптації КСКМ.

Таблиця 8

Скорегований валовий прибуток ПрАТ «Князя Трубецького»*

\begin{tabular}{|c|c|c|c|}
\hline Рік & Індекс споживчих цін & $\begin{array}{c}\text { Валовий прибуток } \\
\text { фактичний, тис. грн. }\end{array}$ & $\begin{array}{c}\text { Валовий прибуток } \\
\text { скорегований, тис. грн. }\end{array}$ \\
\hline 2013 & 1,120 & 3405,90 & 3040,98 \\
\hline 2014 & 1,254 & 5790,50 & 4617,62 \\
\hline 2015 & 1,224 & 22137,99 & 18086,59 \\
\hline 2016 & 1,191 & 29004,00 & 24352,64 \\
\hline 2017 & 1,186 & 29072,80 & 24513,32 \\
\hline
\end{tabular}

* Розраховано авторами на основі даних підприємства

Результати кореляційно-регресійного аналізу наведемо у табл.9.

Таблиця 9

Ключові показники кореляційно-регресійного аналізу залежності валового прибутку від рівня адаптації КСКМ ПрАТ «Князя Трубецького»*

\begin{tabular}{|l|c|c|c|c|}
\hline $\begin{array}{c}\text { № } \\
\text { 3/п }\end{array}$ & Показник & Значення & $\begin{array}{c}\text { Нормативне } \\
\text { значення }\end{array}$ & Інтерпретація \\
\hline 1. & Коефіцієнт кореляції & 0,878 & {$[-1 ; 1]$} & зв'язок між змінними тісний \\
\hline 2. & R-квадрат & 0,771 & {$[0 ; 1]$} & $\begin{array}{c}\text { задовільна апроксимація, модель в } \\
\text { цілому адекватна явищу, що опису- } \\
\text { ється }\end{array}$ \\
\hline 3. & Значимість F & 0,050 & $<0.05$ & модель в цілому значуща \\
\hline 4. & Рівняння регресії & & $1931,63 \mathrm{x}-15463,15$ \\
\hline
\end{tabular}


Згідно отриманих результатів, модель можна вважати адекватною та значущою.

Висновки та перспективи подальших досліджень. Швидкі зміни зовнішнього середовища вимагають від підприємств виноробної промисловості пристосування їхнього внутрішнього середовища для досягнення максимальної фінансової ефективності. Адаптація комунікативної складової комплексу маркетингу підприємства передбачає розроблення і реалізацію найбільш дієвого переліку засобів маркетингових комунікацій із врахуванням особливостей характеру діяльності підприємства та в умовах мінливості зовнішнього середовища його функціонування, результатом якого $є$ зростання ефективності діяльності підприємства.

На сьогоднішній день, підприємства виноробної промисловості не повністю використовують наявний потенціал, тому потребують рекомендацій щодо підвищення рівня адаптації КСКМ. Відповідно до проведених розрахунків, рівень адаптації КСКМ ПрАТ «Князя Трубецького» можливо підвищити на 2,670 балів за рахунок перегляду набору засобів маркетингових комунікацій, його розширення за рахунок тих, що найбільше формують стійку лояльність споживачів до торговельної марки.

Науковою новизною даної роботи є розроблення методичного підходу до оцінювання рівня адаптації комунікативної складової комплексу маркетингу підприємства до мінливих ринкових умов. Практична значущість полягає у тому, що запропонований підхід дозволяє підвищити глибину обгрунтованості управлінських рішень щодо планування довгострокового розвитку підприємства виноробної промисловості завдяки комплексному вивченню зовнішнього і внутрішнього середовища функціонування підприємства та формуванню найбільш ефективного комплексу маркетингових комунікацій, що відповідає сучасним ринковим умовам і дозволяє підвищити економічну ефективність роботи підприємства.

Подальшим напрямом дослідження є розроблення шляхів підвищення рівня адаптації комунікативної складової комплексу маркетингу за рахунок формування такого набору засобів маркетингових комунікацій, що найбільше відповідає сучасним ринковим умовам.

\section{Література}

1. Ліпова О.Л., Черевата Т.М. Адаптивність як ключовий фактор конкурентоспроможності підприємства // Економіка харчової промисловості. 2018. Т.10, Вип. (1). С. 38-45; doi: 10.15673/fie.v10i1.864

2. Большой латинско-русский он-лайн словар: веб-сайт. URL: http://linguaeterna.com/vocabula/alph.php (дата звернення 21.11.2017)

3. Будник М.М. Адаптація промислових підприємств до ринкових умов господарювання: автореф. дис. на здобуття наук. ступеня канд. екон. наук: 08.06.01: захист 28.03.2002 / наук кер. В.М. Гриньова. Харків, 2002. $18 \mathrm{c}$.

4. Шевченко В.В. К вопросу о сущности экономической адаптации // Вестник института экономических исследований. 2016. №1. С.20-39. URL: https://cyberleninka.ru/article/v/k-voprosu-o-suschnostiekonomicheskoy-adaptatsii. (дата звернення 23.10.2017)

5. Райзберг Б.А., Лозовский Л.Ш., Стародубцева Е.Б. Современный экономический словарь, 2-е изд., испр. - Москва. 1999. 479 с. 2003. $688 \mathrm{c}$.

6. Экономико-математический энциклопедический словарь / Гл. ред. Данилов-Данильян В.И. Москва,

7. Бричко А.М. Адаптація регіональної економічної системи до постійно змінних факторів внутрішнього та зовнішнього середовища URL: http://journal.udau.edu.ua/assets/files/88/eko/ukr/27.pdf. (дата звернення 23.10.2017)

8. Дудчак В.В. Теоретико-методологические аспекты формирования системы адаптивного управления промышленными предприятиями: автореф. дис. докт. экон. наук: спец. 08.06.01: защита 02.04.06 / научн. руковод. В.М. Джуха. Ростов-на-Дону, 2006. 59 с.

9. Артеменко В.Б., Агафонова М.С. Вопросы адаптации экономических систем к инновациям // Фундаментальные исследования. Серия экономические науки. 2013. № 10. С. 1995-1999.

10. Пастухова Е.А. Адаптация экономической системы к изменениям среды // Современные наукоемкие технологии. 2006. №5. С.77-80.

11. Марковская Е.И. Теоретические и практические аспекты адаптации моделей поведения экономических субъектов // Вестник балтийской педагогической академии. 2013. № 111. С. 6-16.

12. Зяблицкая Н.В. Современные положения теории адаптации // Электронный научный журнал «Управление экономическими системами», 2011. URL: http://www.uecs.ru/uecs-36-122011/item/877-2011-12-2111-49-33. (дата звернення 25.10.2017)

13. Ластаев Т.Т., Кайгородцев А.А. Механизм агропромышленной интеграции // Вестник КАССУ. 2006. №4. C. 10-12.

14. Алєксєєв С. Б. Формування адаптивного управління підприємствами вугільного машинобудування: автореф. дис. на здобуття наук. ступеня кандидата екон. наук : спец. 08.06.01: захист 19.06.2003 / наук кер. Л.В. Пронченко. Донецьк, 2003. 23 с. 


\author{
Фомишина В.Н. \\ доктор экономических наук, профеессор \\ E-mail: fomishyna.vira@kntu.net.ua \\ Федорова H.Е. \\ аспирант \\ кафедра внешнеэкономической деятельности \\ Херсонский национальный технический университет \\ Бериславское шоссе, 24, г. Херсон, Украина, 73008 \\ E-mail: fedorova.nadiya@kntu.net.ua
}

\title{
ОПРЕДЕЛЕНИЕ УРОВНЯ АДАПТАЦИИ КОММУНИКАТИВНОЙ СОСТАВЛЯЮЩЕЙ КОМПЛЕКСА МАРКЕТИНГА ВИНОДЕЛЬЧЕСКОГО ПРЕДПРИЯТИЯ (НА ПРИМЕРЕ ЧАО «КНЯЗЯ ТРУБЕЦКОГО»)
}

Современные условия хозяйствования предприятий винодельческой промышленности, в которых возрастает степень изменчивости внешней среды и обостряется конкуренция, требуют от предприятий приспособления к их действию через адаптацию всех направлений деятельности, в частности, комплекса маркетинга и его составляющих. Ведь именно адаптация предоставляет предприятию возможность избегать кризисных явлений, эффективно конкурировать и расширяет диапазон его рыночных возможностей. Целью данного исследования является определение динамики показателя уровня адаптации коммуникативной составляющей комплекса маркетинга винодельческого предприятия, нахождение резервов его роста для разработки в дальнейшем рекомендаций по повышению эффективности деятельности предприятия. В статье дано определение понятию «адаптация коммуникативной составляющей комплекса маркетинга (КСКМ)» предприятия. Описана методика определения уровня адаптации коммуникативной составляющей комплекса маркетинга винодельческого предприятия. Представлены и разделены на возможности и угрозы наиболее влиятельные составляющие внешней среды винодельческих предприятий Херсонской области в 2013-2017 гг. Определены и разделены на сильные и слабые стороны элементы внутренней среды предприятия винодельческой промышленности (на примере ЗАО «Князя Трубецкого»). Построены матрицы определения направлений реализации средств коммуникативной составляющей комплекса маркетинга исследуемого предприятия за 2013-2017 гг. Описаны мероприятия, реализуемые предприятием в рамках существующего комплекса маркетинговых коммуникации. Установлен уровень адаптации коммуникативной составляющей комплекса маркетинга исследуемого предприятия. Выявлена взаимосвязь между уровнем адаптации коммуникативной составляющей комплекса маркетинга и валовой прибылью предприятия с помощью корреляционно-регрессионной модели. Определены неиспользованные возможности повышения экономической эффективности функционирования предприятия за счет роста показателя уровня адаптации коммуникативной составляющей комплекса маркетинга.

Ключевые слова: адаптация, уровень адаптации, коммуникативная составляющая, маркетинговые коммуникации, комплекс маркетинга, внешняя среда, внутренняя среда, винодельческая промышленность.

\author{
Fomishyna V. \\ Doctor of Economics, Professor, \\ E-mail: fomishyna.vira@kntu.net.ua \\ Fedorova N. \\ Postgraduate \\ Department of Foreign Economic Activity \\ Kherson National Technical University \\ Beryslavske highway, 24, Kherson, Ukraine, 73008 \\ E-mail: fedorova.nadiya@kntu.net.ua
}

\section{DETERMINATION OF THE LEVEL OF ADAPTATION OF THE MARKETING MIX COMMUNICATION COMPONENT OF A WINERY (BY THE EXAMPLE OF PRJSC “KNIAZIA TRUBETSKOHO”)}

Modern wine industry market conditions can be characterized as inconstant and highly competitive. They compel enterprises to adjust all spheres of their activity, especially marketing mix and its components, with the help of adaptation mechanisms. The adaptation gives to the enterprise an opportunity to avoid crises, compete effectively and widen the range of its market opportunities. The aim of the research is to determine the dynamics of the level of adaptation of communication component of marketing mix of a winery, finding reserves of its growth for future development of the recommendations for enterprise's economic effectiveness increase. In the article the determination of the term "the adaptation of the communication compo- 
nent of marketing mix" of the enterprise has been given. The method of determination of the level of adaptation of the communication component of marketing mix of the winery has been described. The most important elements of the external environment of wineries in Kherson region in 2013-2017 years have been presented. They are divided into opportunities and threats. The most important elements of the internal environment of wineries have been presented (by the example of PrJSC "Kniazia Trubetskoho"). They are divided into strengths and weaknesses. Matrixes of determination of the ways of realization of means of communication component of marketing mix of the studied winery in 2013-2017 years have been built. The activities realized by the enterprise in the context of existing communication mix have been described. The present level of adaptation of communication component of marketing mix of winery has been determined. The link between the level of adaptation of the communication component of marketing mix and the gross profit of the enterprise has been discovered using the correlative-regression model. The unused opportunities to increase the economic effectiveness of the enterprise with the help of the level of adaptation of the communication component of marketing mix growth have been determined.

Key words: adaptation, level of adaptation, communication component, marketing communications, marketing mix, external environment, internal environment, wine industry.

\section{References}

1. Lipova, O. L., \& Cherevata, T. M. (2018). Adaptyvnist yak kliuchovyi faktor konkurentospromozhnosti pidpryiemstva. Ekonomika Kharchovoi Promyslovosti, 10(1), 38-45. doi:10.15673/fie.v10i1.864

2. Bolshoy latinsko-russkiy on-layn slovar. Retrieved November 21, 2017, from http://linguaeterna.com/vocabula/alph.php

3. Budnyk, M. M. (2002). Adaptatsiia promyslovykh pidpryiemstv do rynkovykh umov hospodariuvannia: Avtoref. dys. na zdobuttia nauk. stupenia kand. ekon. nauk: 08.06.01. Kharkiv.

4. Shevchenko, V. V. (2016). K voprosu o suschnosti ekonomicheskoy adaptatsii. Vestnik Instituta Ekonomicheskih Issledovaniy, (1), 20-39. Retrieved October 23, 2017, from https://cyberleninka.ru/article/v/k-voprosu-osuschnosti-ekonomicheskoy-adaptatsii

5. Rayzberg, B. A., Lozovskiy, L. Sh., \& Starodubtseva, E. B. (1999). Sovremennyiy ekonomicheskiy slo$\operatorname{var}$ (2nd ed.). Moskva.

6. Danilov-Danilyan, V. I. (Ed.). (2003). Ekonomiko-matematicheskiy entsiklopedicheskiy slovar. Moskva.

7. Brychko, A. M. (2015). Adaptatsiia rehionalnoi ekonomichnoi systemy do postiino zminnykh faktoriv vnutrishnoho ta zovnishnoho seredovyshcha. Retrieved October 23, 2017, from http://journal.udau.edu.ua/assets/files/88/eko/ukr/27.pdf

8. Dubchak, V. V. (2006). Teoretiko-metodologicheskie aspektyi formirovaniya sistemyi adaptivnogo upravleniya promyishlennyimi predpriyatiyami: Avtoref. dis. dokt. ekon. nauk: Spets. 08.06.01. Rostov-na-Donu.

9. Artemenko, V. B., \& Agafonova, M. S. (2013). Voprosyi adaptatsii ekonomicheskih sistem k innovatsiyam. Fundamentalnyie Issledovaniya,(10), ekonomicheskie nauki, 1995-1999.

10. Pastuhova, E. A. (2006). Adaptatsiya ekonomicheskoy sistemyi k izmeneniyam sredyi. Sovremennyie Naukoemkie Tehnologii, (5), 77-80.

11. Markovskaya, E. I. (2013). Teoreticheskie i prakticheskie aspektyi adaptatsii modeley povedeniya ekonomicheskih sub'ektov. Vestnik Baltiyskoy Pedagogicheskoy Akademii, (111), 6-16.

12.Zyablitskaya, N. V. (2011). Sovremennyie polozheniya teorii adaptatsii. Elektronnyiy Nauchnyiy Zhurnal «Upravlenie Ekonomicheskimi Sistemami». Retrieved October 25, 2017, from http://www.uecs.ru/uecs-36122011/item/877-2011-12-21-11-49-33

13. Lastaev, T. T., \& Kaygorodtsev, A. A. (2006). Mehanizm agropromyishlennoy integratsii. Vestnik KASSU, (4), 10-12.

14. Alieksieiev, S. B. (2003). Formuvannia adaptyvnoho upravlinnia pidpryiemstvamy vuhilnoho mashynobuduvannia: Avtoref. dys. na zdobuttia nauk. stupenia kandydata ekon. nauk: Spets. 08.06.01. Donetsk.

Received 17 August 2018

Approved 31 August 2018

Available in Internet 17.10.2018

Цитування згідно ДСТУ 8302:2015

Фомішина В.М., Федорова Н.Є. Визначення рівня адаптації комунікативної складової комплексу маркетингу виноробного підприємства (на прикладі ПрАТ «Князя Трубецького») // Економіка харчової промисловості. 2018. Т. 10, Вип. 3. С. 48-56; doi: 10.15673/fie.v10i3.1061

Cite as APA style citation

Fomishyna, V., \& Fedorova, N. (2018). Determination of the level of adaptation of the marketing mix communication component of a winery (by the example of PrJSC "Kniazia Trubetskoho"). Food Industry Economics, 10(3), 48-56 ; doi: 10.15673/fie.v10i3.1061 